\title{
Characterization and Properties of Sri Lankan Coir Fibre
}

\author{
Dineth S. Samarawickrama
}

\begin{abstract}
This study mainly concentrated on revealing the scientific data on the properties of Sri Lankan coir fibre and classifying them into different grades based on scientific parameters instead of visual observations to establish quality specifications for the coir fibre industry in Sri Lanka. Critical parameters were studied for suitability of the industrial applications. Size distribution and average length of different fibres were determined by the frequency distribution method, to be used as industrial oriented parameters. The weighted average breaking load of coir fibre was determined using the universal tensile strength tester.

As per the result, coir fiber has an elongation property of about 20-28\%. Also, coir fibre is a highly resilient natural fibre and Omat coir fibre had the highest value among other coir fibre types. Porous microstructure of the coir fibre was observed through the scanning electron microscopy and hygroscopic characteristics described according to the structure. The moisture equilibrium values of coir fibre in Sri Lanka were observed at $15-18 \%$ and it was achieved by sun drying. This moisture levels avoid the heavy condensation during transportation particularly in countries with cold climate. Properties of coir fibre found in the study were used in the establishment of the National Quality Standard specifications for mechanically extracted coir fibre in Sri Lanka.
\end{abstract}

Keywords: coir fibre, Sri Lanka, quality standards, coir properties.

Materials Technology Section, Industrial Technology Institute, 363, Bauddhaloka Mawatha, Colombo 07, Sri Lanka. Email: dineth@iti.lk 


\section{Introduction}

Coir fibre is one of the widely used industrial fibres in the world for various industrial end uses. Mainly four types of coir fibres are produced in Sri Lanka, namely Bristle fibre, Omat fibre, Mattress Fibre and Mixed (Mix) fibre. The traditional process mainly gives "Bristle" ("One tie") and "Mattress" types. Also "Two-tie" and "Three-tie" fibre types are produced by the combing (hackling) of "One tie" and "Two-tie" fibre respectively. Combed fibres are used to produce brushes and other value added products. Fibre that becomes separated at the combing process is shorter than bristle fibre and categorized as Omat fibre. Some producers prepare the "Omat" type by further cleaning of Bristle types using turbo cleaners. De-fibering process mainly produces the "Bristle", "Omat" and "Mattress" types. Decorticators and D1 processes are used to extract "Mixed" fibre type comprising all the fibrous components in coconut husk.

The main problem that limited the development of the Sri Lankan coir industry was the lack of knowledge on characteristics and non availability of a standard for coir fibre types. Usually, the buyer comes to an agreement with the supplier on the quality of fibre he requires solely based on visual examination, without any scientific basis. The present study was conducted to fill the gap between the scientific basis and the current practice based on visual observations. As a result, "Sri Lankan Standard for Mechanically Extracted Coir Fibre" (SLS 115 Part 1: 2009) was published, which positively improved the status of the coir industry in meeting international demands. Suitable test methods for determining characteristics of the coir fibre had not been established before the commencement of this project. Previous Sri Lanka Standard (SLS 115) addressed only the value added bristle fibre (SLS 115 Part 1: 1981) and retted white fibres (SLS 115 Part 4: 1975). The main objective of this study was to propose a realistic classification and standardization of Sri Lankan coir fibre. This helps to overcome the conflicts and/or misunderstanding among buyers and suppliers.

\section{Materials and methods}

The utility of coir for commercial applications is determined by its physical, chemical and mechanical properties. Samples of various types of coir fibre were collected according to the previous SLS 115 Part 1: 1981 standard $^{1}$, from various parts of Sri Lanka where different processing methods are used. Test methods were developed by the adaptation of the previous national and foreign standards, considering evolving industrial needs and the experience of the officers involved. The following main characteristics were analyzed in this study.

\section{Characteristics Studied}

1. Length distribution, \% (by weight and by number of fibres)

2. Average Length, mm

3. Fineness, $\mathrm{g} / \mathrm{km}$

4. Weighted Average Diameter, mm

5. Weighted Average Breaking load, $\mathrm{N}$

6. Weighted Average Tensile Strength, N $\mathrm{mm}^{-2}$

7. Weighted Average Elongation, $\%$

8. Resilience, $\%$

9. Chloride content, $\%$

10. $\mathrm{pH}$ value

11. Water absorption

12. Colour coordinates (L, C, H, a, b)

Fibre samples were tested for the above characteristics at the Industrial Technology Institute of Sri Lanka according to the laboratory developed test methods.

\section{Types of Fibre}

Types of fibre produced in Sri Lanka are;

Bristle Fibre

Mattress Fibre

Omat Fibre

Mixed Fibre

Considering the physical characteristics of Sri Lankan Coir Fibre types:

Bristle fibre is the lengthy, stiff fibre, having highest breaking load compared to other coir types. Normally bristle fibres are used for 
manufacturing brushes, heavy-duty yarns and twines.

Omat fibre is the mixture of long and short sized fibre, showing medium values for its properties, normally used in twine and yarn production, for geo-textiles, and upholstery industry.

Mattress fibre has least values for the physical properties and highest tensile strength. Potentially, mattress fibres are used for mattress and upholstery preparations and lengthy mattress fibre can be used for further value addition.

Mixed fibre is the mixture of total fibres obtained from the husk either using decorticator or D1 machine. Potential uses of mixed fibre are as raw material for yarn and twine production and other relatively less value added processes.

\section{Results and discussions}

\section{Length Distribution}

Length is a very important property for fibre. That determines the spin ability, twisting, and other commercial uses of coir. High variation of length of coir fibre strands within the same husk is observed. Branching at one end or at both ends is also commonly found in coir fibre. This is an unusual occurrence in other natural fibres. Average length of the fibre type was calculated by the frequency distribution method with $25 \mathrm{~mm}$ class width, as shown in Table 1 as percentage number of fibres and in Table 2 as percentage weight of fibres in each class.

Fibre size distribution was calculated according to the number and weight of fibre in 25 $\mathrm{mm}$ class intervals as a percentage. Graphical presentation of the length distribution as percentage number of fibres in each class is given in Figure 1. Accordingly Bristle fibre shows the "nearly normal distribution" shape than other types. Mattress fibre shows the exponential type/size distribution shape. The other two types show intermediate behavior. The size distribution as weight percentage is given in Figure 2, where bristle fibre having more like normal distribution shape and omat fibres and other two types deviated from the normal distribution. The combination of the two size distribution graphs, i.e. as number percentage and weight percentage of each class gives a correct picture of the coir fibre types. In other words these size distributions can be used as a measuring tool to categorize fibre samples and to select the compatible fibre type. This information is very useful in industrial applications, like composite preparation, packing and other value added applications.

\section{Colour}

Color is a matter of perception and subjective interpretation. There is no physical scale for measuring color unlike weight or length. Even looking at the same object people will draw upon different reference and experience and express exactly the same color in vastly different words. Colour of coir varies from pale yellow to dark brown. It mainly depends on the coconut variety; maturity of nuts, time elapsed between husking and retting, quality of water used for retting, as well as duration of soaking or retting. It is mostly brown, within slight variations. Hence it is extremely difficult to express color in coir.

The word "Color" is a mixture of three attributes, namely Hue, Lightness and Saturation. By creating scales for hue, lightness and saturation, color can be expressed numerically in much the same way we express length and weight. Munsell expressed color according to their hue (Munsell hue), lightness (Munsell value) and saturation, (Munsell Chroma) for visual comparison with a specimen color. Other methods for expressing color numerically were developed by an international organization concerned with light and color, The Commission Internationale de Éclair age (CIE). Two most widely known of these methods are the Yxy color space devised band on the tristimulus value XYZ defined by CIE. $L^{*} a^{*} b^{*}$ Color space devised later to provide more uniform color differences in relation to visual differences. $\mathrm{L}^{*} \mathrm{C} * \mathrm{~h}$ Color space use the same diagram as the " $\mathrm{L}^{*} \mathrm{a} \mathrm{a}^{*}$ color space, but uses cylindrical coordinates instead of rectangular coordinates. In the color space, " $\mathrm{C}$ "is chroma, and " $h$ " is the hue angle. The value $\mathrm{C}$ is 0 (zero) at the center. Lightness $\mathrm{L}^{*}$ is the 
Table 1. Length distribution of fibre types based on \% Number of fibres

\begin{tabular}{|l|r|r|r|r|r|r|r|r|}
\hline \multirow{2}{*}{$\begin{array}{l}\text { Size range } \\
\mathbf{m m}\end{array}$} & \multicolumn{2}{|c|}{ Bristle Fibre } & \multicolumn{2}{c|}{ Omat Fibre } & \multicolumn{2}{c|}{ Mattress Fibre } & \multicolumn{2}{c|}{ Mixed Fibre } \\
\cline { 2 - 10 } & $\begin{array}{c}\text { Average } \\
\text { \%/N }\end{array}$ & $\begin{array}{c}\text { St. Dev } \\
+/-\end{array}$ & $\begin{array}{c}\text { Average } \\
\text { \% N/N }\end{array}$ & $\begin{array}{c}\text { St. Dev } \\
+/-\end{array}$ & $\begin{array}{c}\text { Average } \\
\text { \% N/N }\end{array}$ & $\begin{array}{c}\text { St. Dev } \\
+/-\end{array}$ & $\begin{array}{c}\text { Average } \\
\text { \% N/N }\end{array}$ & $\begin{array}{c}\text { St. Dev } \\
+/-\end{array}$ \\
\hline $\mathbf{1 - 2 5}$ & 7.13 & 4.04 & 15.06 & 7.14 & 37.10 & 5.31 & 20.26 & 5.15 \\
\hline $\mathbf{2 6 - 5 0}$ & 5.35 & 2.06 & 14.49 & 4.42 & 25.45 & 3.52 & 24.46 & 5.63 \\
\hline $\mathbf{5 1 - 7 5}$ & 5.27 & 1.46 & 11.37 & 2.45 & 15.56 & 1.91 & 15.63 & 1.11 \\
\hline $\mathbf{7 6 - 1 0 0}$ & 7.01 & 1.29 & 10.22 & 1.73 & 8.82 & 1.63 & 11.35 & 2.08 \\
\hline $\mathbf{1 0 1 - 1 2 5}$ & 7.99 & 1.24 & 8.69 & 1.36 & 5.03 & 0.84 & 7.98 & 1.78 \\
\hline $\mathbf{1 2 6 - 1 5 0}$ & 10.33 & 1.47 & 9.38 & 1.63 & 3.46 & 0.69 & 5.97 & 1.76 \\
\hline $\mathbf{1 5 1 - 1 7 5}$ & 12.20 & 1.81 & 8.81 & 2.13 & 2.06 & 0.60 & 4.64 & 1.61 \\
\hline $\mathbf{1 7 6 - 2 0 0}$ & 12.71 & 1.54 & 7.96 & 2.55 & 1.22 & 0.57 & 3.82 & 1.45 \\
\hline $\mathbf{2 0 1 - 2 2 5}$ & 13.35 & 2.65 & 6.18 & 2.69 & 0.70 & 0.41 & 2.55 & 1.02 \\
\hline $\mathbf{2 2 6 - 2 5 0}$ & 10.48 & 2.64 & 4.51 & 2.64 & 0.37 & 0.23 & 1.75 & 0.88 \\
\hline $\mathbf{2 5 1 - 2 7 5}$ & 6.00 & 1.33 & 2.28 & 1.31 & 0.16 & 0.19 & 1.14 & 0.69 \\
\hline $\mathbf{2 7 6 - 3 0 0}$ & 1.93 & 1.23 & 0.92 & 0.78 & 0.06 & 0.10 & 0.42 & 0.23 \\
\hline $\mathbf{3 0 1 - 3 2 5}$ & 0.25 & 0.55 & 0.08 & 0.14 & 0.01 & 0.03 & 0.42 & 0.02 \\
\hline
\end{tabular}

Table 2. Length distribution based on \% Weight of fibres

\begin{tabular}{|l|r|r|r|r|r|r|r|r|}
\hline \multirow{2}{*}{$\begin{array}{l}\text { Size range } \\
\mathbf{m m}\end{array}$} & \multicolumn{2}{|c|}{ Bristle Fibre } & \multicolumn{2}{c|}{ Omat Fibre } & \multicolumn{2}{c|}{ Mattress Fibre } & \multicolumn{2}{c|}{ Mixed Fibre } \\
\cline { 2 - 9 } & $\begin{array}{c}\text { Average } \\
\text { \%W/W }\end{array}$ & $\begin{array}{c}\text { St. Dev } \\
+/-\end{array}$ & $\begin{array}{c}\text { Average } \\
\text { \%W/W }\end{array}$ & $\begin{array}{c}\text { St. Dev } \\
+/-\end{array}$ & $\begin{array}{c}\text { Average } \\
\text { \%W/W }\end{array}$ & $\begin{array}{c}\text { St. Dev } \\
+/-\end{array}$ & $\begin{array}{c}\text { Average } \\
\text { \%W/W }\end{array}$ & $\begin{array}{c}\text { St. Dev } \\
+/-\end{array}$ \\
\hline $\mathbf{1 - 2 5}$ & 0.25 & 0.22 & 1.25 & 1.02 & 8.13 & 2.74 & 2.54 & 1.36 \\
\hline $\mathbf{2 6 - 5 0}$ & 0.61 & 0.35 & 2.85 & 1.83 & 12.52 & 2.67 & 6.63 & 3.84 \\
\hline $\mathbf{5 1 - 7 5}$ & 1.33 & 0.61 & 3.97 & 1.76 & 14.50 & 2.66 & 8.00 & 3.11 \\
\hline $\mathbf{7 6 - 1 0 0}$ & 2.77 & 0.86 & 5.73 & 2.21 & 13.47 & 2.51 & 8.98 & 2.14 \\
\hline $\mathbf{1 0 1 - 1 2 5}$ & 4.43 & 0.91 & 7.21 & 2.18 & 12.22 & 1.83 & 9.75 & 1.70 \\
\hline $\mathbf{1 2 6 - 1 5 0}$ & 7.27 & 1.50 & 10.24 & 1.83 & 11.76 & 2.01 & 10.29 & 0.46 \\
\hline $\mathbf{1 5 1 - 1 7 5}$ & 11.29 & 1.93 & 12.54 & 2.19 & 9.40 & 2.33 & 11.60 & 1.39 \\
\hline $\mathbf{1 7 6 - 2 0 0}$ & 14.80 & 1.97 & 15.50 & 1.93 & 6.97 & 2.79 & 11.70 & 3.12 \\
\hline $\mathbf{2 0 1 - 2 2 5}$ & 20.12 & 3.75 & 15.42 & 2.59 & 6.08 & 2.91 & 11.27 & 2.44 \\
\hline $\mathbf{2 2 6 - 2 5 0}$ & 18.81 & 3.74 & 13.36 & 3.95 & 3.41 & 1.89 & 9.63 & 3.23 \\
\hline $\mathbf{2 5 1 - 2 7 5}$ & 12.77 & 2.36 & 8.12 & 2.89 & 1.37 & 1.11 & 6.94 & 3.35 \\
\hline $\mathbf{2 7 6 - 3 0 0}$ & 4.73 & 3.18 & 3.29 & 2.16 & 0.97 & 2.06 & 2.59 & 1.28 \\
\hline $\mathbf{3 0 1 - 3 2 5}$ & 0.83 & 1.46 & 0.52 & 1.06 & 0.18 & 0.65 & 0.07 & 0.11 \\
\hline
\end{tabular}


Figure 1. Length Distribution of Sri Lankan Coir Types based on \% number of fibres in classes

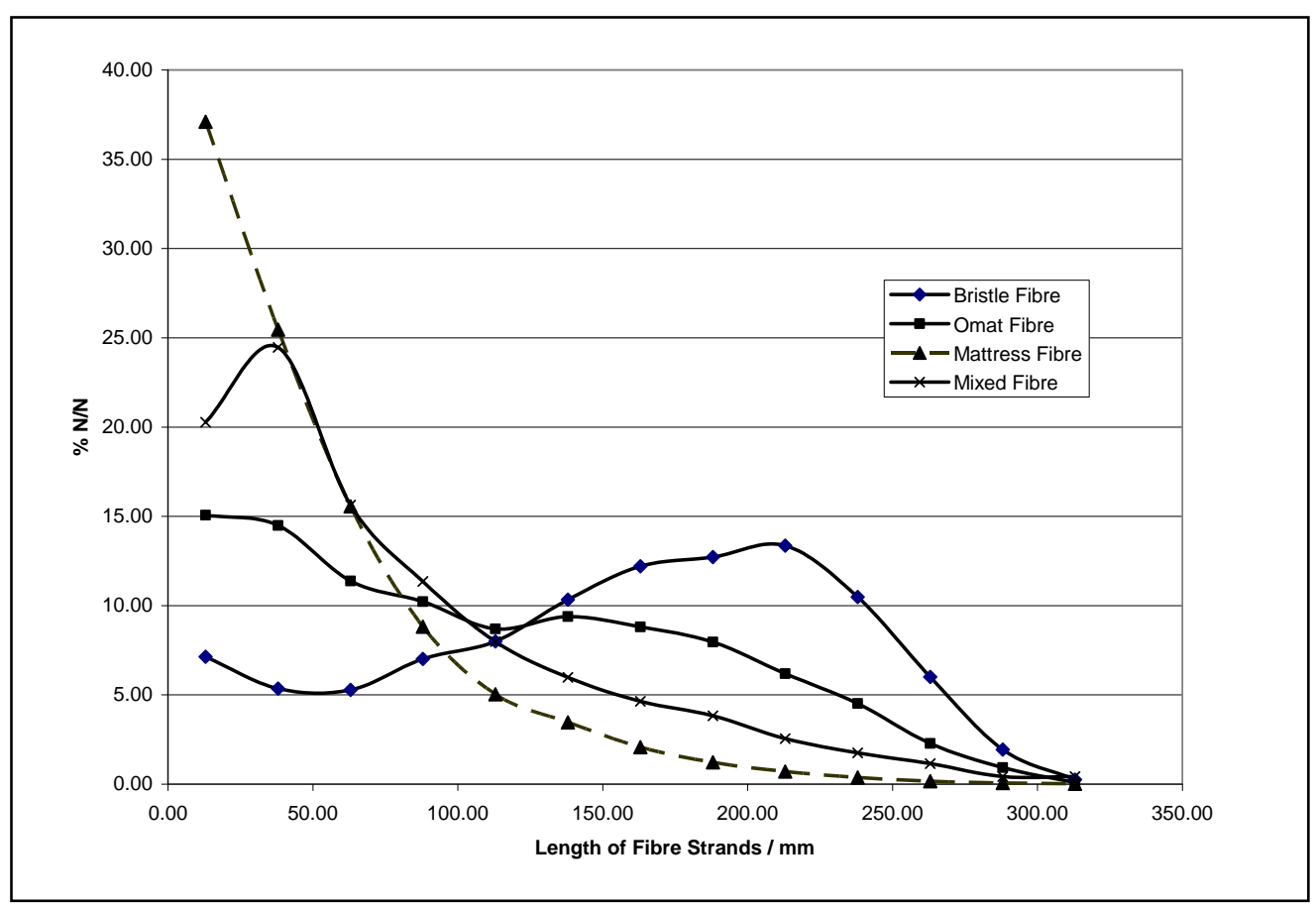

Figure 2. Length Distribution of Sri Lankan Coir Types based on \% weight of fibres in classes

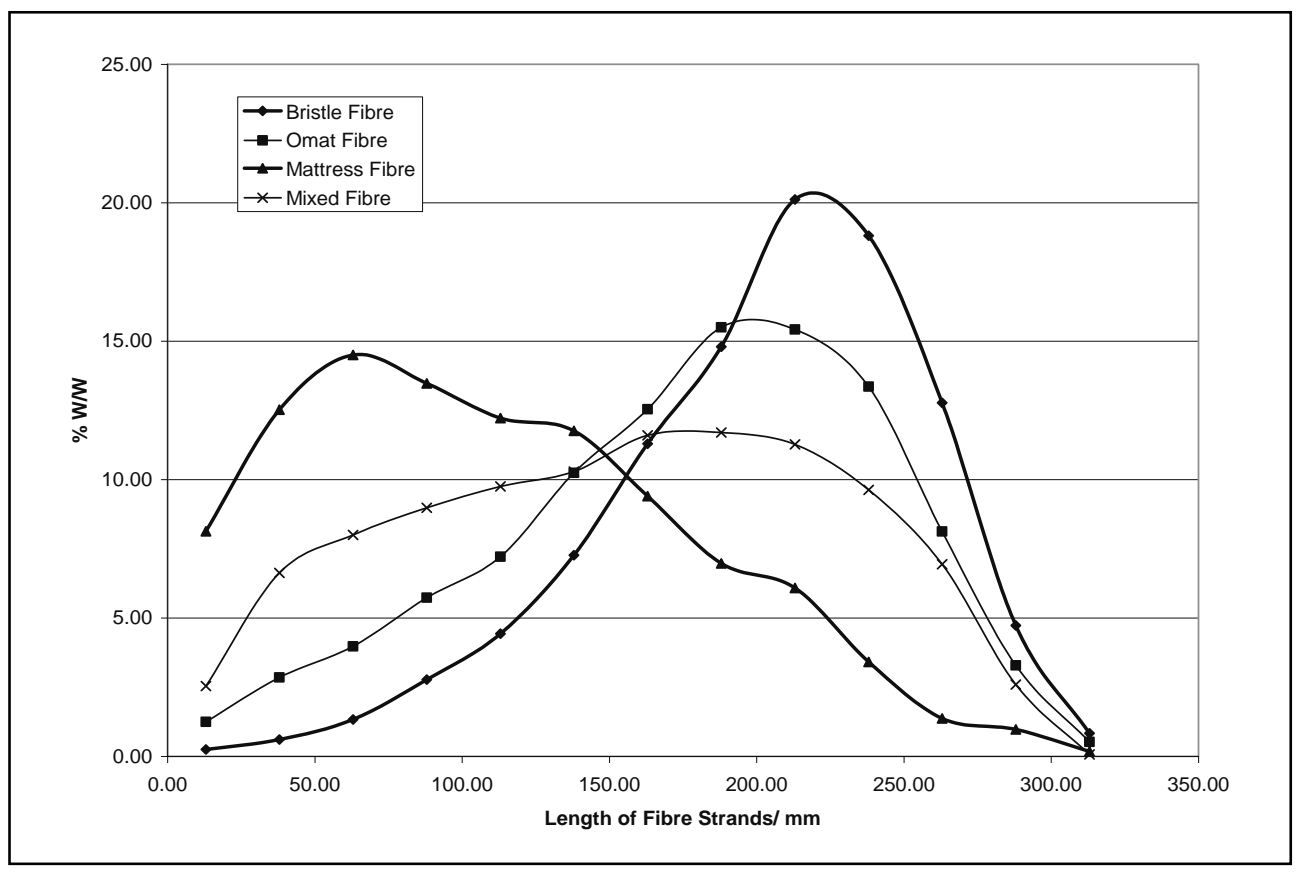


same as " $\mathrm{L}^{*}$ " in the $\mathrm{L}^{*} \mathrm{a} \mathrm{b}^{*}$ color space; Metric Chroma $\mathrm{C}^{*}$ and Metric Hue angle $\mathrm{h}$ are defined by following formulae, ${ }^{2}$

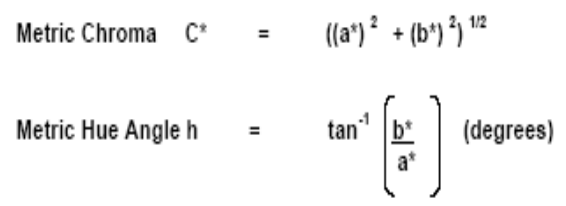

When $a^{*}$ and $b^{*}$ : Chromatic coordinates is the $\mathrm{L}^{*} \mathrm{a} * \mathrm{~b}^{*}$ color space. $\mathrm{L}^{*} \mathrm{a}^{*} \mathrm{~b}^{*}$ Color Space (is also referred as the CIE LAB Space) is one of the uniform color spaces defined by the CIE in 1976. The values $L^{*}, a^{*}$ and $b^{*}$ are calculated according to the formula: ${ }^{2}$

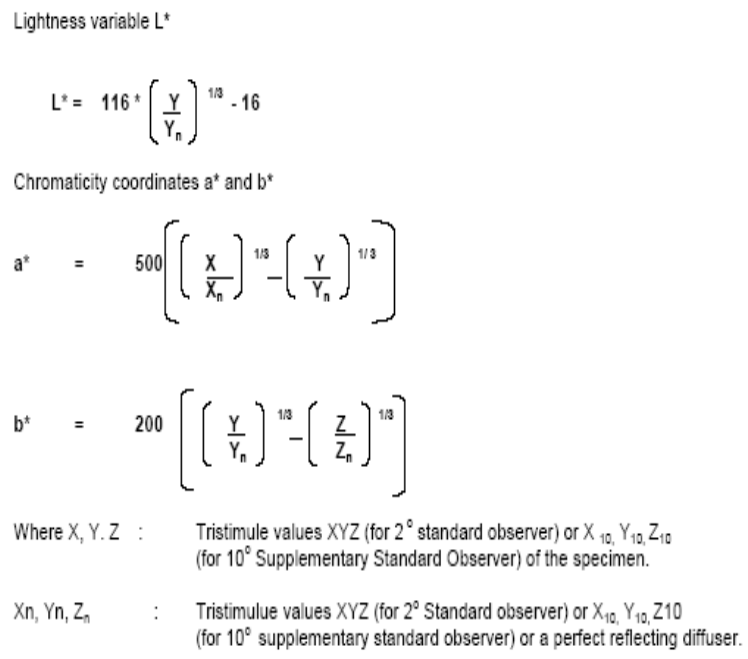

Colorimeter (Tristimulus Method) Model CR 300 manufactured by Minolta Co. Ltd. Japan was used for the test. Test samples were prepared using coir pads, $10 \mathrm{~cm}$ x $10 \mathrm{~cm}$ and approximately $15 \mathrm{~mm}$ in thickness. Colorimeter was calibrated using standard. Colour at three different points of the pads was determined. The microprocessor of the colorimeter automatically calculates above parameters. Colour coordinates varied uniformly in all types of fibres as shown in Table 5, but it is slightly differ from the maturity of the husk and processing conditions.

\section{Moisture content}

Water absorption of the coir types was showing small deviations due to the adhered coir pith as impurity, and structural variations of fibres. The microscopic view of the coir fibre in
Figure 3 shows that it is highly porous fibre and has the ability to hold water in its structure ${ }^{3}$.

Coir Fibre is also a hygroscopic material having the ability to absorb moisture in the form of a gas. Characteristics of the air in a closed container are controlled by the temperature and moisture content of a hygroscopic material within the container. If vapor pressure of the material is much greater than the vapor pressure of the air, water vapor will always flow from an area of high vapor pressure to an area of low vapor pressure. Water vapor pressure in air depends on moisture content. Vapour pressure in a hygroscopic commodity (a solid) depends on two factors namely, the moisture content and the temperature of the commodity. Vapour pressure, dew point, temperature and specific humidity all vary in direct proportion to one another and have corresponding values.

More commonly, the moisture equilibria for solids are given as relationships between the relative humidity of air and the moisture content of solids on a dry basis. Equilibrium moisture curves for Omat and mattress types of fibre at different dry bulb temperatures are given in Figure 4.

The absorption of moisture affects the properties of coir, such as tensile strength, elastic recovery, electrical resistance, rigidity. As a result of water absorption the fibre tend to swell, and this will cause changes in the size, shape, stiffness, and permeability of the products such as yarn or ropes. When dry fibres are exposed to the humid atmosphere they take up moisture and come to equilibrium, similarly when moist fibre is placed in a dry atmosphere it gives up moisture and reaches equilibrium.

As a ship containing hygroscopic matter, proceeds from a warm climate to a cold climate, it will experience a gradual drop in atmospheric dew point as well as a drop in dry bulb temperature. Under these conditions, a danger of heavy condensation of water on the ships hold and top decks exists. The air in the lower deck spaces will take up moisture from the hygroscopic commodities and unless proper ventilation is provided, heavy condensation is certain when the temperature drops. Analyzing 
Figure 3. Fibre surface and longitudinal section ${ }^{3}$
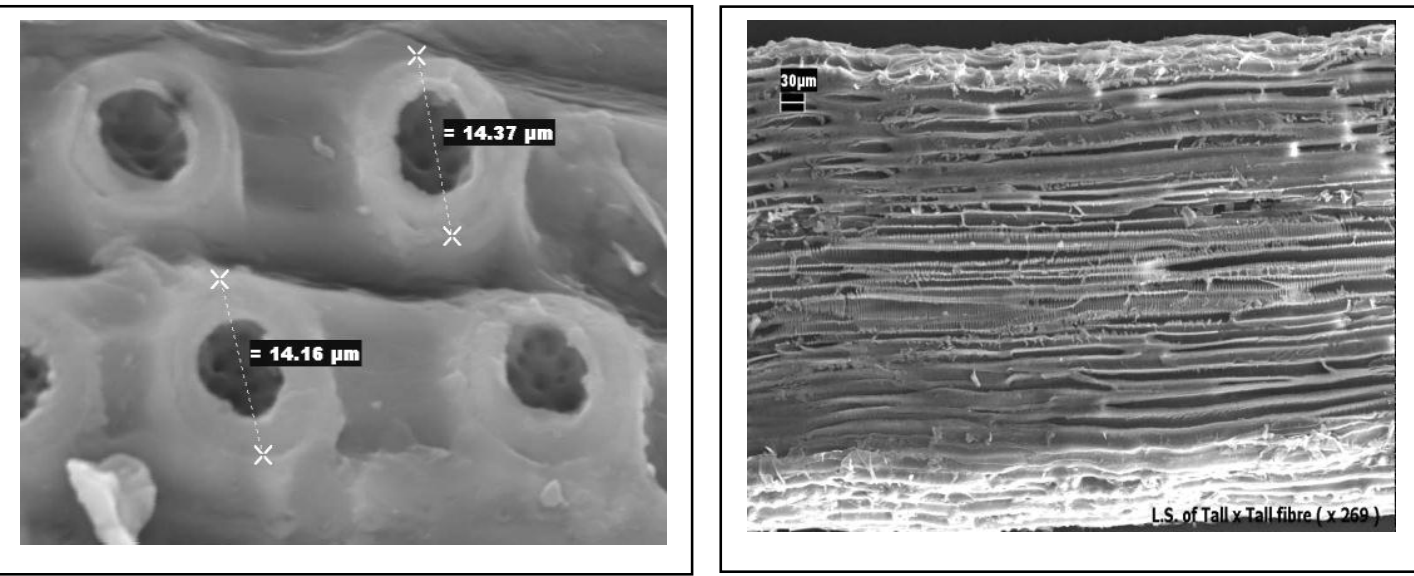

Figure 4a. Equilibrium Moisture content of Mattress fibre

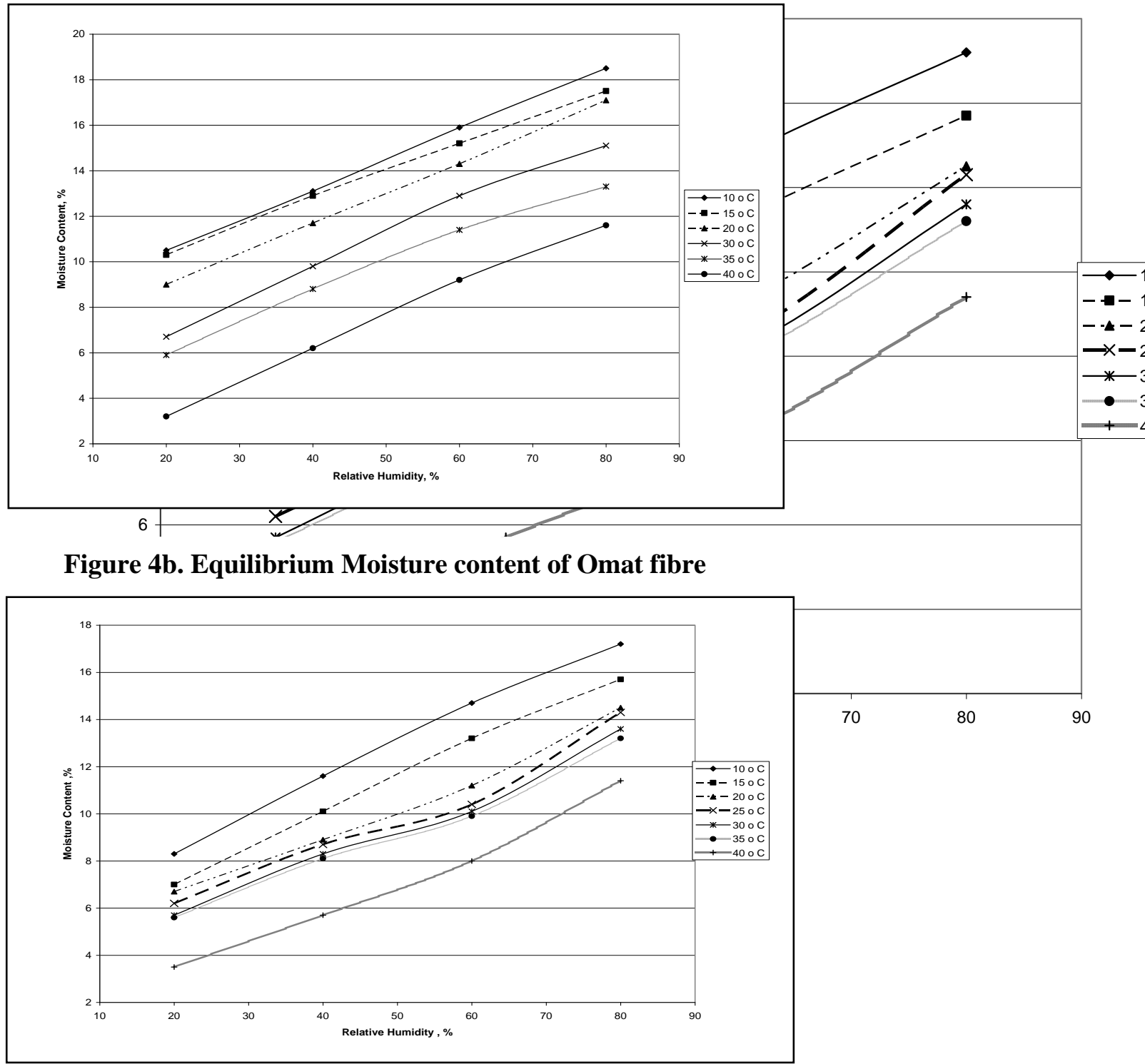


the results obtained from the tests, an average moisture content of 15-18 \% could be attained by sun drying and this could avoid the condensation of moisture when the coir bales are exported to cold countries like Europe ${ }^{4}$.

\section{Mechanical Properties}

\section{Resilience}

Resilience expresses the amount of energy stored up in a body when one unit volume of the body is stressed or compressed. It is measured as a percentage deviation from the original volume after releasing the compression force.

Resilience is the most important property in the mattress and upholstery industries. Also it is important for packing purposes. Resilience of the needle punch coir sheets $(10 \mathrm{~cm} \mathrm{x} 10 \mathrm{~cm})$ was determined in $10 \mathrm{~cm}$ high piles for different types of coir fibre. Results are given in Figure 5. Omat fibre is showing undesirably higher values than other three types. The long: short fibre ratio and other characteristics of Omat fibre is the reason for that behavior. Normally, mixtures of Omat and mattress fibres are used in various industries like upholstery and mattress preparation.

\section{Fineness}

Fineness was calculated by the moisturefree weight of a fibre sample (in grams0 divided by the total length of the fibre sample in kilometers. This is also a measure of linear density in Tex $(1 \mathrm{Tex}=1 \mathrm{~g} / 1000 \mathrm{~m})$ in the textile industry. Concerning other characteristics, fineness too varies with the fibre types (Bristle, Mattress, Omat or Mixed). The main reason for this variation is the size distribution patterns of each fibre grade as indicated above.

\section{Other Mechanical Properties}

Weighted average values of the breaking load, tensile strength and percentage elongation were calculated by using the weight factor of the fibre strands in the $50 \mathrm{~mm}$ class width in the sample (six classes). A maximum of 10 fibres in each $50 \mathrm{~mm}$ fibre class were tested for their corresponding characteristics. The strength properties were determined by the universal strength tester with $250 \mathrm{~N}$ load cell at 40 $\mathrm{mm} /$ minute rate.
Breaking load is the maximum force applied when a fibre strand is broken in tension. Weighted average breaking load of fibre depends on the diameter, and the highest breaking load was observed for long fibre. Hence Breaking Load of the fibre types also shows the same relationship as in Table 3.

Table 3. Variation of Weighted Average Breaking Load with fibre type

\begin{tabular}{|l|c|}
\hline Fibre Type & $\begin{array}{c}\text { Range of Breaking Load / } \\
\text { N }\end{array}$ \\
\hline Bristle & $3.0-6.5$ \\
\hline Omat & $2.7-5.6$ \\
\hline Mattress & $1.6-5.2$ \\
\hline Mixed & $2.8-3.6$ \\
\hline
\end{tabular}

Tensile strength is expressed as the breaking load per unit area of cross section of the fibre strand. Therefore the value depends on the diameter of fibres. Since mattress fibre has the lowest average diameter, the tensile strength of mattress fibre is higher than other types. Percentage elongation of the fibres is apparently similar in three types while bristle fibre has relatively less elongation than other three types.

\section{Chemical properties}

\section{Composition}

Coconut fibre (coir fibre) is a lignocellulosic fibre which comprises $32.7 \%$ lignin and $35.6 \%$ of cellulose ${ }^{5}$. Coir has the highest lignin content when compared to other plant fibres but less than wood fibre (14-37\% $)^{6}$.

Lignin in the cell walls gives rigidity and colour to the fibres and fibre bundles. It also reduces permeation of water across the cell walls. Lignin also plays an important role in the transport of water, nutrients, and metabolites in the vascular system of plants. Further, lignin in plant cells helps to maintain the rigidity of the cell wall, and it gives resistance towards compressions and bending as well as protection against attacks by micro organisms.

Having a high percentage of lignin, coir has a good natural resistance to soiling and dampness. In a hot climate it gives cool comfort and in cold weather it retains warmth. 
Figure 5. Resilience of Sri Lankan Coir Fibre

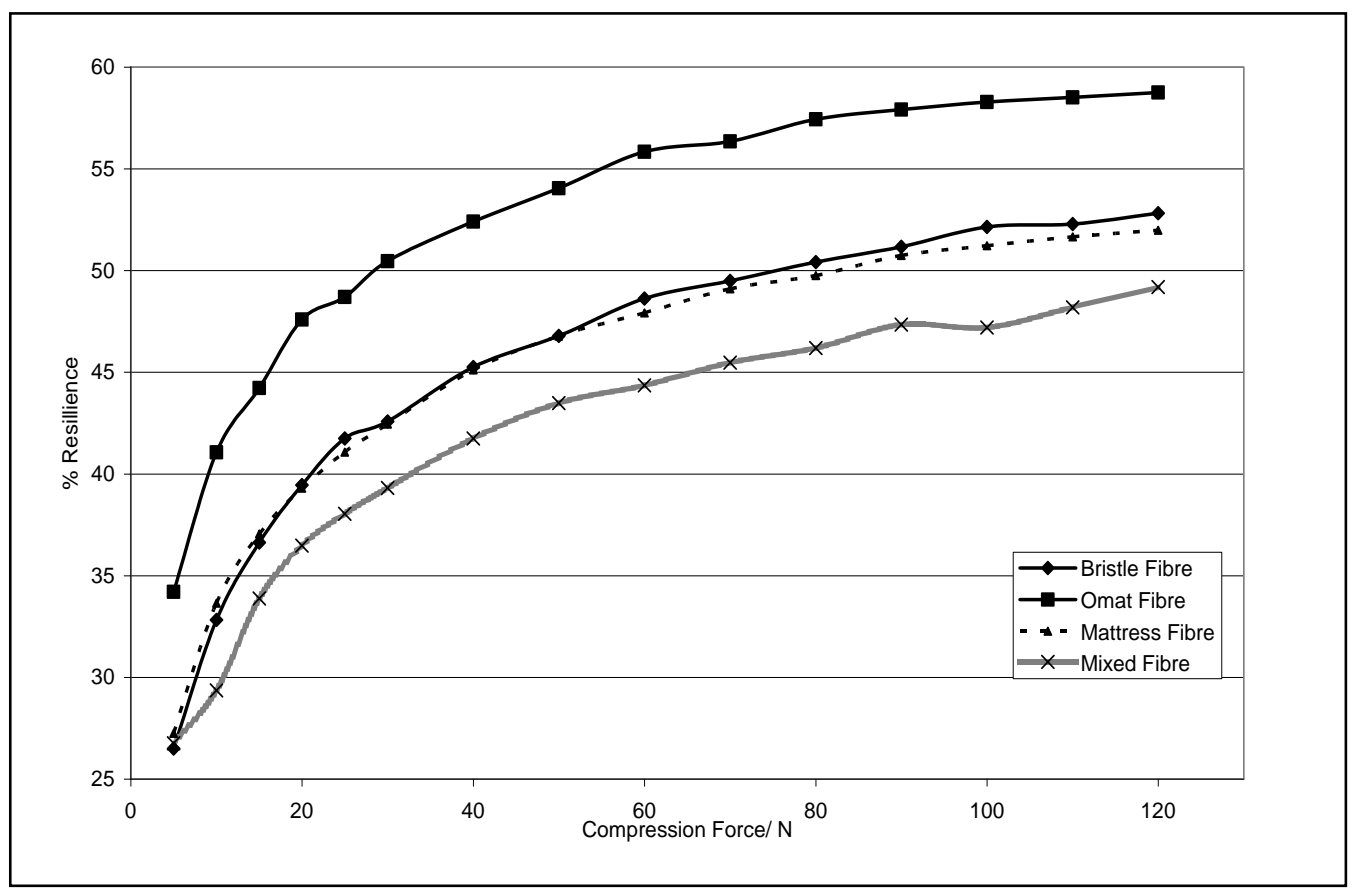

Table 4. Physical Properties of Sri Lankan Coir types

\begin{tabular}{|c|c|c|c|c|c|c|c|c|}
\hline \multirow[t]{2}{*}{ Characteristic } & \multicolumn{2}{|c|}{$\begin{array}{c}\text { Bristle Fibre } \\
(\mathbf{n}=20)\end{array}$} & \multicolumn{2}{|c|}{$\begin{array}{c}\text { Omat Fibre } \\
(n=21)\end{array}$} & \multicolumn{2}{|c|}{$\begin{array}{c}\text { Mattress Fibre } \\
(n=29)\end{array}$} & \multicolumn{2}{|c|}{$\begin{array}{c}\text { Mixed Fibre } \\
(\mathbf{n}=\mathbf{5})\end{array}$} \\
\hline & Average & $\begin{array}{l}\text { St. } \\
\text { Dev }\end{array}$ & Average & $\begin{array}{l}\text { St. } \\
\text { Dev }\end{array}$ & Average & $\begin{array}{c}\text { St. } \\
\text { Dev }\end{array}$ & Average & $\begin{array}{c}\text { St. } \\
\text { Dev }\end{array}$ \\
\hline Average Length, mm & 155.02 & 12.17 & 110.85 & 22.80 & 49.69 & 7.29 & 77.65 & 13.70 \\
\hline Fineness, g/km & 47.66 & 7.03 & 34.95 & 6.93 & 19.34 & 3.33 & 27.37 & 3.18 \\
\hline $\begin{array}{l}\text { Weighted Average } \\
\text { Diameter, mm }\end{array}$ & 0.20 & 0.03 & 0.16 & 0.02 & 0.12 & 0.01 & 0.13 & 0.01 \\
\hline $\begin{array}{l}\text { Weighted Average } \\
\text { Breaking Load, N }\end{array}$ & 4.96 & 0.82 & 4.07 & 0.80 & 2.81 & 0.82 & 3.11 & 0.31 \\
\hline $\begin{array}{l}\text { Weighted Average Tensile } \\
\text { Strength, } \mathrm{N} \mathrm{mm}^{-2}\end{array}$ & 126.95 & 17.29 & 165.81 & 27.05 & 231.73 & 74.10 & 170.83 & 23.47 \\
\hline $\begin{array}{l}\text { Weighted Average } \\
\text { Elongation, \% }\end{array}$ & 20.63 & 1.70 & 22.07 & 2.87 & 24.38 & 4.94 & 23.57 & 0.80 \\
\hline $\begin{array}{l}\text { Chloride Content, \% of } \\
\text { Fibre }\end{array}$ & 0.35 & 0.27 & 0.28 & 0.14 & 0.32 & 0.23 & 1.09 & 0.71 \\
\hline pH of Fibre & 6.52 & 0.34 & 6.54 & 0.27 & 6.42 & 0.24 & 6.68 & 0.45 \\
\hline $\begin{array}{l}\text { Water Adsorption, \% of } \\
\text { Fibre }\end{array}$ & 69.76 & 9.97 & 71.19 & 5.38 & 78.59 & 8.27 & 72.05 & 10.48 \\
\hline \multicolumn{9}{|l|}{ Colour Co-ordinates } \\
\hline $\mathbf{L}$ & 39.64 & 2.57 & 39.96 & 5.11 & 40.45 & 2.25 & 42.28 & 3.26 \\
\hline $\mathbf{C}$ & 21.70 & 1.83 & 21.03 & 1.93 & 21.93 & 1.53 & 22.86 & 1.85 \\
\hline H & 67.73 & 1.60 & 68.56 & 0.82 & 68.25 & 0.84 & 69.36 & 1.63 \\
\hline $\mathbf{a}$ & 8.23 & 0.94 & 7.70 & 0.87 & 8.13 & 0.72 & 8.03 & 0.52 \\
\hline b & 20.07 & 1.67 & 19.57 & 1.74 & 20.37 & 1.38 & 21.40 & 1.89 \\
\hline
\end{tabular}


The high content of lignin in coir fibre made the fibre tougher and stiffer, compared to other plant based fibres ${ }^{6}$.

The chemicals present in coir fibre show a high $\mathrm{C}: \mathrm{N}$ ratio. Hence the durability of the coir fibre is higher in harsh environmental conditions compared to that of other competitive natural fibres.

\section{Chloride content and $\mathrm{pH}$ value}

Chloride content and $\mathrm{pH}$ value of coir fibre were also determined by cold extraction in water. The chloride content and the $\mathrm{pH}$ are important to get an idea of some critical aspects like vigour of plant growth, corrosion resistance when the fibre is in contact with metallic surfaces, and the degradability.

Chloride content and $\mathrm{pH}$ values of different fibre types are given in Table 4. Accordingly, chloride content of mixed fibre was relatively high, because the samples were collected in coastal areas having a high amount of chloride ions in the soil. Variation of $\mathrm{pH}$ was negligible and varied between 6.42 and 6.68 only.

\section{Conclusion}

The physical properties of coir fibre were studied to provide valuable information for coir based industrial growth. Good values for physical properties are more helpful to use in various novel industrial applications than in traditional applications. The objective of this study to establish a Sri Lankan Standard for mechanically extracted coir fibre was achieved. The characterization and standardization of Sri Lankan coir fibres have shown to be the correct pathway to an industrial revolution in the coir sector in Sri Lanka.

\section{References}

Abdul Khalil et al. (2006). "Cell walls of tropical fibres", BioResources 1(2), 220-232.

"Precise Colour Communication", Minolta Co. Ltd., Radiometric Instruments Operations

Sepa, N.H.A., Y. Nanayakkara (2003). "Characterization and Determination of Properties of Sri Lankan Coconut Fibres". M. Phil Thesis.

Sivaganeshamoorthi, V. et al. (2003). "Equilibrium Moisture Content of Hygroscopic Substance", Chapter 05, Characterization of Sri Lankan Coir Fibre, 155-161

SLS 115 Part 1: 1981 "Specification for coconut fibre (Coir fibre) Part 1: Bristle fibre (First Revision)"

http://www.fao.org/DOCREP/005/Y3612E/y 3612e00.htm 